\title{
Recent-Year-to-Year Variations in Seasonal Temperatures and Sea Ice Conditions in the Eastern Canadian Arctic
}

\author{
JOHN D. JACOBS ${ }^{1}$ and JOHN P. NEWELL ${ }^{2}$
}

\begin{abstract}
Mean summer and winter temperatures for the 1957-1978 period have been analyzed for four eastern Arctic stations. Standard deviations on the order of $3^{\circ} \mathrm{C}$ in winter and $1^{\circ} \mathrm{C}$ in summer indicate the magnitude of the interannual variations, and these departures are found to be synchronous over the region. Several indices of sea ice severity also show significant year-to-year variations, but these are not spatially coherent. Relationships between climatic parameters and sea ice are examined in order to explain these differences.
\end{abstract}

\section{INTRODUCTION}

The 1978-79 winter in the eastern Canadian Arctic began with below average temperatures, including a record November low of $-27.8^{\circ} \mathrm{C}$ at Frobisher Bay, where an early freeze-up prevented completion of the annual resupply of the settlement by sea. Milder temperatures in December and January were followed in February by renewed cold and a succession of severe winter storms which were record-breaking in some areas and resulted in a disruption of transportation and services (Atmospheric Environment Service, 1979).

These recent events are part of a pattern of apparently worsening weather in the region which began in the 1960's with a trend toward cooler summers (Bradley, 1973) and more severe sea ice conditions (Dunbar, 1972). In addition to this trend, there have been large year-to-year variations in both summer and winter temperatures as well as in the amounts of sea ice and the dates of clearing. We have examined the recent record with respect to such interannual variations; in particular, the relative magnitude of interannual variations in seasonal temperatures and maximum sea ice cover, the homogeneity of the record across the region, and relationships between the temperature and sea ice records.

The area considered includes Baffin Island and the surrounding waters of Foxe Basin, Baffin Bay, and Davis Strait (Fig. 1). The temperature records used are those from the first-order meteorological stations at Coral Harbour, Frobisher Bay, Hall Beach, and Clyde River, all located on coasts at low elevations (Table 1). The period of uninterrupted, concurrent operation of all four stations began in 1957. Information on ice conditions is available in a standard form for a somewhat shorter period. 


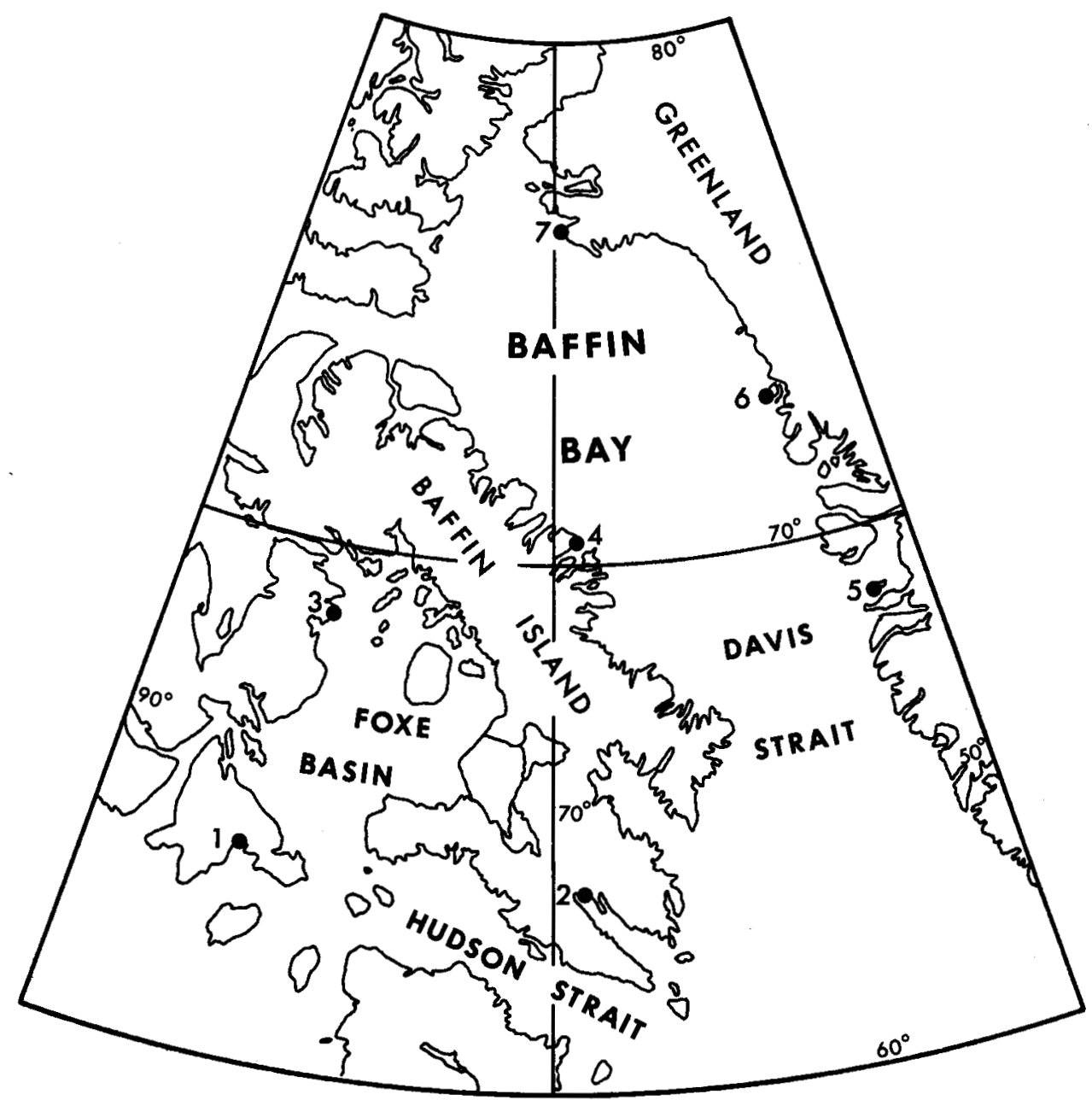

FIG. 1. The Baffin Island Region. Stations referred to in the text are: (1) Coral Harbour, (2) Frobisher Bay, (3) Hall Beach, (4) Clyde River, (5) Egedesminde, (6) Upernavik, and (7) Thule.

\section{TEMPERATURE PATTERNS}

Temperature is the best single indicator of seasonal climatic severity in the Arctic. For the purpose of this study, the months June, July and August are considered to be the summer season and December, January and February the winter. Means and standard deviations of temperatures for these seasons over the 1957-78 period of record were calculated for the four stations, as shown in Table 1. Because means and standard deviations vary across the region, a relative departure was used. This is found by dividing the departure from the mean in a given year at a particular station by its standard deviation. Correlations were run on the summer and winter departures among the four stations, and agreement was found to be good (Table 2) with all correlation 
TABLE 1. TEMPERATURES AND SEA ICE CONDITIONS AT BAFFIN REGION STATIONS

\begin{tabular}{|c|c|c|c|c|}
\hline Station & Clyde & $\begin{array}{c}\text { Frobisher } \\
\text { Bay }\end{array}$ & $\begin{array}{c}\text { Coral } \\
\text { Harbour }\end{array}$ & $\begin{array}{c}\text { Hall } \\
\text { Beach }\end{array}$ \\
\hline $\begin{array}{l}\text { Elevation } \\
\text { (m. a.s.l.) }\end{array}$ & 3 & 21 & 59 & 10 \\
\hline $\begin{array}{l}\text { Mean Winter Temperature }\left({ }^{\circ} \mathrm{C}\right)^{\mathbf{a}} \\
\text { Standard Deviation }\end{array}$ & $\begin{array}{c}-25.9 \\
2.6\end{array}$ & $\begin{array}{c}-24.3 \\
3.4\end{array}$ & $\begin{array}{c}-28.1 \\
2.6\end{array}$ & $\begin{array}{c}-30.2 \\
2.7\end{array}$ \\
\hline $\begin{array}{l}\text { Mean Summer Temperature }\left({ }^{\circ} \mathrm{C}\right)^{\mathrm{a}} \\
\text { Standard deviation }\end{array}$ & $\begin{array}{l}2.9 \\
1.0\end{array}$ & $\begin{array}{l}5.8 \\
1.0\end{array}$ & $\begin{array}{l}6.1 \\
1.4\end{array}$ & $\begin{array}{l}3.5 \\
1.2\end{array}$ \\
\hline $\begin{array}{l}\text { Mean Ice Thickness } \\
\text { Standard deviation }\end{array}$ & $\begin{array}{r}145 \\
9\end{array}$ & $\begin{array}{r}157 \\
16\end{array}$ & $\begin{array}{r}163 \\
16\end{array}$ & $\begin{array}{r}201 \\
31\end{array}$ \\
\hline $\begin{array}{l}\text { Mean Breakup Date } \\
\text { Standard deviation (days) }\end{array}$ & $\begin{array}{c}14 \text { July } \\
11 \\
\end{array}$ & $\begin{array}{c}4 \text { July } \\
14 \\
\end{array}$ & $\begin{array}{c}26 \text { June } \\
14\end{array}$ & $\begin{array}{c}18 \text { June } \\
14\end{array}$ \\
\hline
\end{tabular}

aSource: Atmospheric Environment Service, Monthly Record of Meteorological Observations, (1957-78) Downsview, Ontario.

'Source: Department of Environment, 1974, Ice Thickness Data for Canadian Stations (1958-71), Ottawa.

TABLE 2. CORRELATION ( $\mathrm{r}$ values) of SUMMER/WINTER TEMPERATURES AMONG BAFFIN REGION STATIONS (1957-1978)

(1)

1.0
(2)

$0.70^{\mathrm{a}} / 0.84^{\mathrm{a}}$

1.0
(3)

(4)
Clyde River (1)

Frobisher Bay (2)

Coral Harbour (3) $0.70^{\mathrm{a}} / 0.73^{\mathrm{a}}$

$0.81^{\mathrm{a}} / 0.54^{\mathrm{b}}$

$0.70^{\mathrm{a}} / 0.87^{\mathrm{a}}$

1.0 $0.63^{\mathrm{b}} / 0.80^{\mathrm{a}}$

$0.83^{\mathrm{a}} / 0.92^{\mathrm{a}}$

Hall Beach (4) 1.0

${ }^{a} r$-values significant at the $0.1 \%$ level or higher

${ }^{b}$ r-values significant at the $1 \%$ level or higher

coefficients significant at the $1 \%$ level or better. The region can therefore be considered homogeneous in this respect.

Averaging the seasonal temperature departures among the four stations provides a measure of the interannual fluctuations across the region as a whole. Figure 2(a) shows the resulting record for the Baffin region. It is seen that the greatest departure in any season is about two standard deviations, with interannual fluctuations on the order of one standard deviation or about $3^{\circ} \mathrm{C}$ in winter and $1^{\circ} \mathrm{C}$ in summer being common.

Serial correlations were carried out on this record to determine whether or not there was a connection between winter temperatures and those of the subsequent summer, between successive summers and winters, or whether 


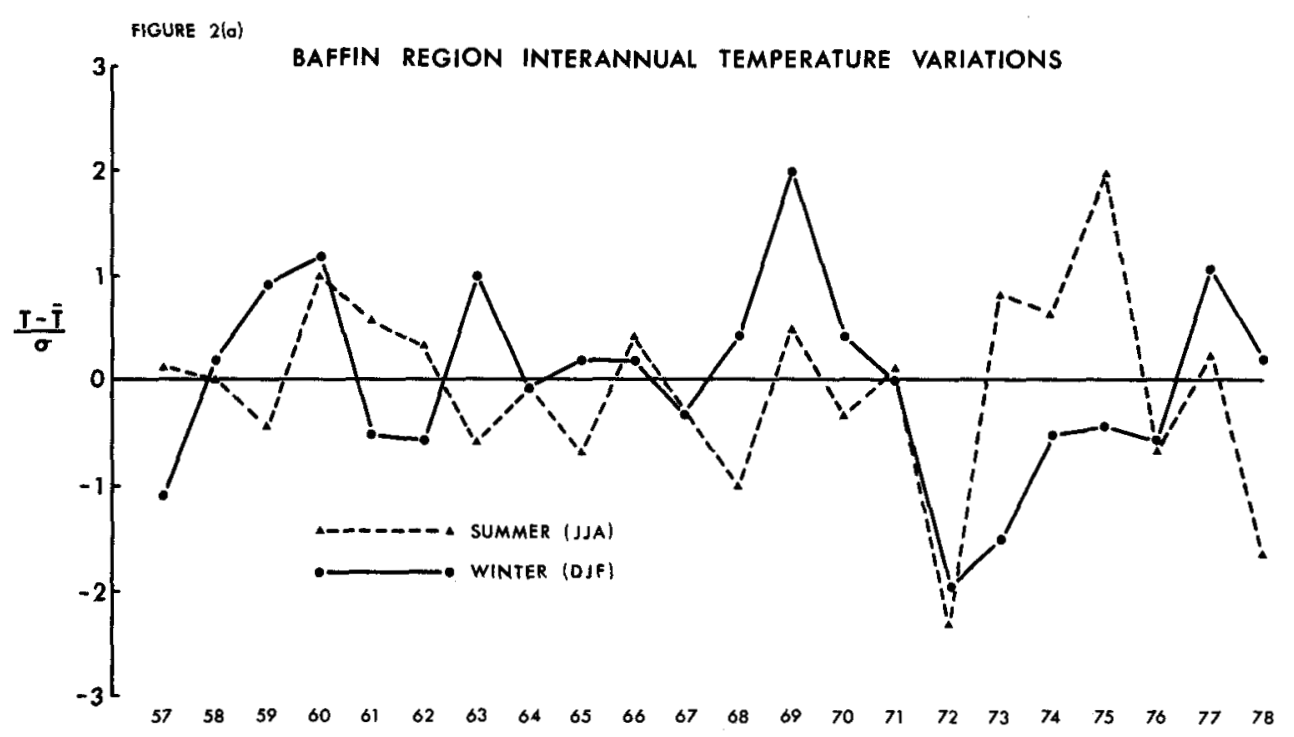

FIG. 2(a) Baffin Region interannual temperature variations. Values shown are yearly departures from the seasonal mean (1957-78) divided by the standard deviation for the same period.

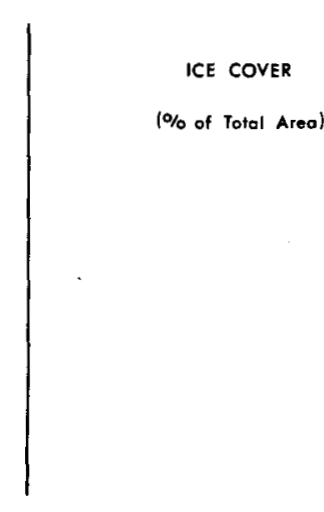

FIGURE 2 (b)

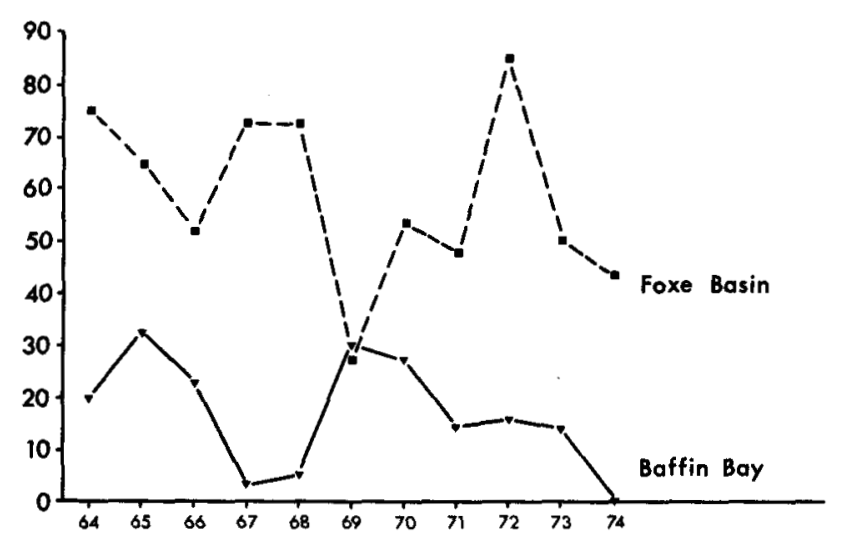

SEA ICE COVER AT END OF AUGUST

FIG. 2(b) Sea ice cover (percent of area) in Foxe Basin and Baffin Bay at the end of August (1964-74).

there was evidence of a biennial oscillation, which should show up as a serial correlation with a one-year lag. In all of these cases, the correlations were so low as to be considered not significant on the basis of Student's t-test.

A comparison was made between seasonal temperatures at Clyde and those for each of three Greenland stations: Egedesminde, Upernavik, and Thule (Department of Commerce, 1968). No significant correlation was found, 
suggesting that Baffin Island and northwest Greenland are distinct regions, climatically.

\section{SEA ICE CONDITIONS}

Sea ice data published for the Baffin region stations include freeze-up dates, weekly measurements of ice thickness and snow cover, and dates of breakup and clearing (Department of Environment, 1961-71). Although local bathymetry, tides and currents affect the growth of landfast ice, the relative thickness in a particular year reflects average winter and early spring temperatures. Relationships between accumulated degree-days below freezing and ice growth are well-known (Bilello, 1961). The progress of decay and breakup of the fast ice is in part determined by the amount of ice present, but is largely controlled by summer temperatures and winds (Jacobs, et al., 1975).

The two variables, maximum annual ice thickness and breakup date, were examined for the four Baffin Island stations (Table 1). The ice thickness values used were the maximum thicknesses prior to the onset of melting of the snowpack, usually in the latter party of May. Values measured later are sometimes higher, but include superimposed ice which results from the refreezing at the sea ice surface of water from the melting snowpack.

The resulting mean thicknesses for the thirteen-year period vary across the region in a way that is generally consistent with mean winter temperature patterns. Standard deviations indicative of interannual variations are from 6 to 15 percent of the means, with Hall Beach showing the largest.

As was done for seasonal temperatures, the degree of regional homogeneity of the interannual ice thickness variations was tested by correlation. The results (Table 3) show that there is little or no correlation among the stations, with the exception of that between Clyde River and Hall Beach where the correlation is only marginally significant. The implication is that local controls on ice growth tend to override the effects of regional temperature patterns in determining the relative thickness of the fast ice in a given year.

It is difficult to determine from the published data the exact date of breakup. In some years this is explicitly stated, in others the date is given on which the ice was found "unsafe," while in many only the date of the last

TABLE 3. CORRELATION. ( $\mathrm{r}$ values) of ANNUAL MAXIMUM ICE THICKNESS AMONG BAFFIN REGION STATIONS (1959-72)

Clyde River (1)

Frobisher Bay (2)

Coral Harbour (3)
(1) (2)

(2) (3)

$\begin{array}{lll}1.0 & -0.39 & -0.10\end{array}$

$1.0 \quad 0.43$

1.0
(4)

$0.57^{\mathrm{a}}$

0.00

0.47

Hall Beach (4) 
TABLE 4. CORRELATION ( $r$ values) OF BREAK-UP DATES AMONG BAFFIN REGION STATIONS (1959-72)

\begin{tabular}{lcccc} 
& $(1)$ & $(2)$ & $(3)$ & $(4)$ \\
\hline Clyde River (1) & 1.0 & -0.28 & -0.05 & 0.00 \\
Frobisher Bay (2) & & 1.0 & 0.10 & -0.15 \\
Coral Harbour (3) & & & 1.0 & -0.34 \\
Hall Beach (4) & & & & 1.0 \\
\hline
\end{tabular}

None significant.

measurement is given. Since the practice is to make measurements weekly until the ice becomes unsafe or breaks up, these dates all describe about the same stage of ice decay. The resulting dates (Table 1) are slightly earlier than but consistent with the mean dates of ice clearing for the same stations published by Allen and Cudbird (1971) based on a shorter record.

On average, breakup occurs latest at Clyde on Baffin Bay, and is earliest at Hall Beach on Foxe Basin. The latter fact is interesting, considering the great thickness of ice attained at Hall Beach and the relatively cool summers there compared with Frobisher Bay and Coral Harbour. At Hall Beach, however, the observations are made at an exposed location, while at the other three stations measurements are made in bays and inlets (Allen and Cudbird, 1971).

The year-to-year variations in breakup dates show no correlation among the four stations (Table 4). As with ice thickness, local factors appear to modify the effects of the general regional climatic controls.

The amount of ice cover over extensive ocean areas at the end of the summer season should be more representative of regional conditions than is the inshore ice. Maps of ice cover are available for the Canadian Arctic on a weekly basis from early May through the end of August (Department of Environment, 1964-76). A planimeter was used on these maps to find the area covered by ice in Baffin Bay and Foxe Basin at the end of August in each year from 1964-1974. The results, expressed as percentage of total basin area, are shown in Figure 2(b).

It is seen that extensive ice cover remains in Foxe Basin throughout the summer. In both Foxe Basin and Baffin Bay-Davis Strait, ice tends to concentrate on the western sides of the basins and remain into late autumn and even until freeze-up in some years (Canadian Hydrographic Service, 1970). Interannual variations are large; however, there is little year-by-year correspondence between amounts in the two areas. A correlation between the two yielded an $r$-value of -0.23 , suggesting an opposite phase, although this was not statistically significant. What can be concluded is that the areal extent of sea ice, which should reflect summer climate as well as winter, is highly variable on a year-to-year basis and that the variations follow a different pattern in Foxe Basin from that in Baffin Bay. 
TABLE 5. CORRELATION (r values) BETWEEN ICE CONDITIONS AND SEASONAL TEMPERATURE DEPARTURES

\begin{tabular}{lcccc} 
& $\begin{array}{c}\text { Clyde } \\
\text { River }\end{array}$ & $\begin{array}{c}\text { Frobisher } \\
\text { Bay }\end{array}$ & $\begin{array}{c}\text { Coral } \\
\text { Harbour }\end{array}$ & $\begin{array}{c}\text { Hall } \\
\text { Beach }\end{array}$ \\
\hline $\begin{array}{l}\text { Maximum Ice Thickness and } \\
\begin{array}{l}\text { Winter Temperature Departures } \\
\text { Breakup Date and }\end{array}\end{array}$ & 0.14 & $-0.69^{\mathrm{a}}$ & -0.39 & -0.33 \\
$\begin{array}{l}\text { Summer Temperature Departures } \\
\text { lumer }\end{array}$ & 0.01 & -0.02 & 0.10 & -0.18 \\
\hline
\end{tabular}

${ }^{a}$ Significant at the $1.0 \%$ level.

\section{RELATIONSHIPS BETWEEN CLIMATE AND SEA ICE CONDITIONS}

The physical linkages between atmosphere and ocean in a sea ice environment are fairly well understood (Weller, 1968; Jacobs, et al., 1975). In view of this, the interannual variations of seasonal temperatures and sea ice severity should show some relationship to each other. However, the fact that the high degree of spatial coherence exhibited by the temperature variations is not matched in any of the indices of ice severity suggests that such relationships are not simple ones.

Correlations carried out between maximum ice thicknesses and winter temperature departures and between breakup dates and summer temperature departures confirm that supposition (Table 5). In only one case, that between maximum ice thickness and winter temperature at Frobisher Bay, was there a significant correlation.

There is better agreement when the regional ice patterns shown in Figure 2(b) are used. Table 6 shows correlations between Foxe Basin ice cover and Hall Beach temperature departures and between Baffin Bay ice cover and Clyde temperature departures. The severity of ice in Foxe Basin at the end of summer is clearly related to temperature departures in the summer and preceding winter, as well as to ice thickness. The Baffin Bay ice, on the other hand, shows no such correlation.

\section{DISCUSSION}

The use of a regional index of sea ice severity, the areal extent of late summer ice, revealed the expected correspondence between interannual variations in seasonal temperatures and ice conditions in Foxe Basin. That this was not also the case in Baffin Bay suggests that other climatic and (possibly) oceanographic factors need to be accounted for there.

Baffin Bay is a deep basin which is relatively unrestricted at the southern, David Strait end through which there is a continuous outflow of drift ice in all months. Although wind stress undoubtedly has some effect upon this movement, it is mainly associated with the strong southward flowing current along the east coast of Baffin Island (Muench, 1971; Walker, 1977). By contrast, while there is some drift of Foxe Basin ice through Foxe Channel 
TABLE 6. CORRELATION ( $\mathrm{r}$ values) BETWEEN REGIONAL ICE EXTENT AND SEASONAL TEMPERATURE DEPARTURES

Foxe Basin/Hall Beach Baffin Bay/Clyde River

1. Winter temperature departures and late August ice $-0.57^{\mathrm{a}}$

2. Summer temperature departures and late August ice $-0.60^{\mathrm{a}}$

3. Maximum ice thickness and late August ice

4. Breakup date and late August ice

${ }^{\text {aS }}$ ignificant at $5 \%$ level.

'Significant at $0.1 \%$ level.

and Hudson Strait (Campbell and Collin, 1958), the greater part of that ice probably melts in situ.

No data are yet available on year-to-year variations in oceanographic conditions in the eastern Arctic, although decadal-scale changes in the strength of the West Greenland Current have been reported (Dunbar, 1976) which affect currents and temperatures in Baffin Bay as well as in Davis Strait. Shorter term effects of circulation changes are moderated by the high heat capacity and inertia of the ocean waters.

Both theory and the evidence from Foxe Basin suggest that a cooler summer means more ice at the end of August and that this will be compounded by a cold winter. Assuming that such conditions also hold in Baffin Bay and that the general outflow of ice is with a steady or only slowly varying current, then the more complex interannual variations in the extent of ice there must be a consequence of other meteorological factors as well. Winds in particular should be important, both through the effects on drift of wind stress and the turbulent exchange of heat from warmer air to the ice through forced convection.

July and August monthly average windspeeds and prevailing directions for Hall Beach and Clyde River were examined for 1964-1974. For that period, winds were northerly to northwesterly at Clyde except for August, 1966 and July, 1967, when they were southerly. For Hall Beach, southerly winds occurred in 1966 (July and August), 1967 (July), 1969 (July and August), and 1973 (July).

The relationship between wind direction and ice conditions is by no means clear. For example, 1969 was a warm, light ice year in Foxe Basin with mainly southerly winds at Hall Beach, but ice conditions were heavy in Baffin Bay, where winds were northwesterly. The cool summers of 1967 and 1968 saw light ice in Baffin Bay, but heavy in Foxe Basin, with winds in July of the former year southerly in both areas but northerly in August, 1967 and in both 
months of the following year. Finally, 1974 was a year of light ice in both areas and summer temperature departures were positive, but winds were northerly at Hall Beach and northwesterly at Clyde.

In general, Foxe Basin tends to have lighter ice conditions in those summers of more frequent southerly airflow and those summers tend also to be warmer. Baffin Bay rarely experiences persistent southerly winds; northerly and north-westerly winds predominate and show little variation in relation to ice conditions.

Monthly averages of winds do not adequately represent the effects of individual weather events. Related studies for the Davis Strait Coast of Baffin Island by Barry, et al., (1978) and Crane (1979) have demonstrated the importance to the progress of breakup of the landfast ice of wind and weather patterns lasting only a few days. These patterns are clearly revealed in the twice-daily synoptic weather maps for the region but tend to be lost in monthly or even weekly mean maps.

Following the example of Dunbar (1972), Crane (1979) classified the years 1964-1974 according to whether there was an "early" or "late" retreat of ice in Davis Strait and the Labrador Sea, as shown by the same ice map series on which we have based Fig. 2(b). He then examined the two groups of years according to the frequency of individual synoptic circulation types using the objective classification of sea-level map patterns of Barry, et al. (1978). This comparison showed that a statistically significant higher frequency of the types with southerly airflow characterizes the years of "early" retreat.

With the exception of 1965, 1966, and 1969, Crane's "early" years in Davis Strait were also years of light late-August ice in Baffin Bay, as indicated by Figure 2(b). The synoptic map pattern Crane found to be most frequent in summers of light ice conditions was a low centred on Foxe Channel. The corresponding airflow would be southerly in Davis Strait and Baffin Bay but more northerly in Foxe Basin. In view of this, it is not surprising that there is some asymmetry between the two regions.

In his analysis of interannual variations of summer ice conditions in the Beaufort Sea, Rogers (1978) found that retreat of the ice was most highly correlated with summer temperatures expressed as thawing degree-days. The frequency of southerly airflow situations, on which temperatures are obviously dependent, also correlated well. The pattern revealed here for the eastern Canadian Arctic is very much the same.

\section{CONCLUSION}

The recent climatic record shows the eastern Canadian Arctic to be characterized by large interannual variations in seasonal temperatures and sea ice conditions. Fluctuations in temperatures are fairly uniform across the region; however, variations in sea ice exhibit less spatial homogeneity. Ice conditions in Foxe Basin follow a different pattern from those in Baffin Bay and Davis Strait.

There is a general, but locally complex correspondence between the severity of summer climate (and to a lesser extent that of the preceding 
winter) and the extent of late summer sea ice. Ice conditions in Foxe Basin correlate well with regional temperature departures, but those in Baffin Bay do not. Winds, and more particularly, the frequency of synoptic-scale events seem to better explain variations in the latter area.

Normal probability considerations applied to the interannual record of Figure 2 gives a probability of occurrence of a temperature departure greater than one standard deviation in either season of 0.32 (about three years in 10) and of two standard deviations or more of 0.05 (one year in twenty). As with any climatic series, projections based on these probabilities should be used cautiously; however, they can at least serve as an indication of the likelihood of a major departure occurring in a particular year.

\section{ACKNOWLEDGEMENTS}

The study of regional and local climates in the eastern Arctic, of which this report forms a part, has been supported by grants from the National Research Council of Canada. Support to J. Newell during the course of this study by NORDCO, Ltd. is gratefully acknowledged.

\section{REFERENCES}

ALLEN, W. T. R. and CUDBIRD, B. S. V. 1971. Freeze-up and Break-up Dates of Water Bodies in Canada. Canadian Meteorological Service (Atmospheric Envrionment Service), Toronto, 144 pp.

ATMOSPHERIC ENVIRONMENT SERVICE, 1979. Canadian Weather Review, 17 (2): 1. Downsview, Ontario.

BARRY, R. G. and JACOBS, J. D. (with others), 1978. Energy Budget Studies in Relation to Fast-Ice Breakup Processes in Davis Strait. Occasional Paper No. 26, Inst. of Arctic and Alpine Research, University of Colorado, Boulder, $284 \mathrm{pp}$.

BILELLO, M. A. 1961. Formation, growth and decay of sea ice in the Canadian Arctic Archipelago. Arctic, 14 (1): 3-24.

BRADLEY, R. S. 1973. Seasonal climatic fluctuations on Baffin Island during the period of instrumental records. Arctic, 26 (3): 230-243.

CAMPBELl, N. J. and COLlin, A. E. 1958. The discoloration of Foxe Basin ice. J. Fish. Res. Bd. Canada, $15(6): 1175-1188$.

CANAdian hydRographic SERviCe 1970. Pilot of Arctic Canada. Vol. I. Department of Energy, Mines and Resources, Ottawa, 247 pp.

CRANE, R. G. 1979. Seasonal variations of sea ice extent in the Davis Strait-Labrador Sea area and relationships with synoptic-scale atmospheric circulation. Arctic, 31 (4): 434-447.

DEPARTMENT OF COMMERCE 1968. World Weather Records (1951-60), Vol. 6. Washington, D.C.

DEPARTMENT OF ENVIRONMENT 1961-71. Ice Thickness Data for Canadian Stations (1958-71), Ottawa.

DEPARTMENT OF TRANSPORT 1964-76. Ice: Summary and Analysis (1964-74), Ottawa.

DUNBAR, MOIRA 1972. Increasing severity of ice conditions in Baffin Bay and Davis Strait. In: Karlsson, T., ed., Sea Ice Proceedings of an International Conference . . . 1971, Reykjavik, National Research Council: 87-93.

DUNBAR, M. J. 1976. Climatic change and northern development. Arctic, 29 (4): 183-193.

JACOBS, J. D., BARRY, R. G. and WEAVER, R. L. 1975. Fast ice characteristics with special reference to the eastern Canadian Arctic. Polar Record, 17 (110): 521-536.

MUENCH, R. D. 1971. The Physical Oceanography of the Northern Baffin Bay Region. The Baffin Bay-North Water Project, Scientific Report 1, Arctic Institute of North America, Montreal, $150 \mathrm{pp}$.

ROGERS, J. C., 1978. Meteorological factors affecting interannual variability of summertime ice extent in the Beaufort Sea. Monthly Weather Review, 106 (6): 890-897.

WALKER, E. R. 1977. Aspects of Oceanography in the Archipelago. Unpublished Manuscript Institute of Ocean Sciences, Patricia Bay, Sidney, B.C., 186 pp.

WELLER, G. 1968. Heat-energy transfer through a four-layer system: air, snow, sea ice, sea water. Journal of Geophysical Research, 73 (4): 1209-20. 